\title{
Analysis of the Role and the Resistance of the Unified Registration of Real Estate (URRE) Basing on Structured Interview from 3 Provinces in China
}

\author{
Yang Jing \\ College of Life and Environmental Science, Minzu University of China, Beijing, China
}

\section{Email address:}

yangjing123456@126.com

\section{To cite this article:}

Yang Jing. Analysis of the Role and the Resistance of the Unified Registration of Real Estate (URRE) Basing on Structured Interview from 3 Provinces in China. Science Innovation. Vol. 4, No. 2, 2016, pp. 27-34. doi: 10.11648/j.si.20160402.11

Received: January 18, 2016; Accepted: February 2, 2016; Published: April 8, 2016

\begin{abstract}
Although the unified registration of real estate (URRE) is very important in reform of national land institution, but implementation of URRE is very difficult. The investigation of the role and resistance of the URRE is beneficial to its implementation, which is in turn helpful to the standardization of tenure administration. For better implementing the URRE, the structured interview method and statistical analysis technique were used to investigate the registration of real estate (RRE) including the real estate registration certificate, the existing registration agency and registration time, the necessity of RRE, the role and the resistance of RRE. It is showed that only $4.1 \%$ interviewees think that it is no use to carry out the URRE, but URRE is of great importance for the anti-corruption, national information control, real estate market standardization, relevant policy implementation, clarification of property rights, elimination of disputes, unified planning management etc. The resistance is certain to be encountered in the process of putting URRE into force. The resistance of URRE is mainly from the people such as officials, the rich and conservative person, etc., which is almost accounting for $73.3 \%$ in all the interviewees.
\end{abstract}

Keywords: Cadastral Management, Unified Registration of Real Estate(URRE), Structured Interview, Registration Role, Registration Resistance

\section{不动产统一登记的用途与阻力分析一基于中国三省市的结构式访谈调研}

\section{杨静}

中央民族大学生命与环境科学学院, 北京, 中国

\section{邮箱}

yangjing123456@126.com

\begin{abstract}
摘要：不动产统一登记是中国土地制度改革的重要举措, 其具体推行具有很大难度。深入研究不动产统一登记的用途和 阻力将有利于不动产统一登记的推行，从而达到促进产权管理规范化的目的。本文采用结构式访谈法考察中国已有的房 产登记凭证、登记凭证的重要性、已有的颁证机构、颁证时间、房产登记的必要性、登记的用途和登记的阻力，并进行 统计分析。数据分析表明只有 $4.1 \%$ 的受访者认为没必要进行不动产统一登记; 不动产统一登记有助于反腐、国家信息掌 控、房地产市场规范化、相关政策推行、产权明晰、规划管理统一等; 在不动产统一登记推行过程中会遇到一定的阻力, 不动产统一登记的阻力主要是官员、富人、思想保守人等人群所带来的阻力, 其中有 $73.3 \%$ 的受访者同意这一观点。
\end{abstract}

关键词：地籍管理, 不动产统一登记, 结构式访谈, 登记用途, 登记阻力 


\section{1. 引言}

自2007年《物权法》颁布以来，如何建立不动产统一 登记已经成为学者讨论的热门话题 [1 - 11]。2013年《中 共中央关于全面深化改革若干重大问题的决定》以来国家 对不动产统一登记的重视及《不动产登记暂行条例》的颁 布都体现了国家实施不动产统一登记的决心，也体现了不 动产统一登记的重要作用和实施的困难。一方面, 深入研 究不动产登记的作用和阻力将有利于不动产统一登记的 推行, 适应当前社会发展的要求, 另一方面也对产权和制 度理论的发展具有深远的影响。

综观不动产登记的研究, 目前的热点主要包括: 不 动产统一登记的法律支撑 [12-15]; 经典登记制度 $[4,5,10,11,16$ - 19]; 具体实施细则 [20 - 27]; 不动产 统一登记的公信力 $[7,28-30]$ 等。从文献分析可以看出, 中国已有的不动产登记法律协调性不高 [31-34]; 登记 制度不完善 [5, 10, 34]; 技术不统一 [35-37]; 公信力不 强 $[7,29,30]$; 监管不到位 $[10,31]$, 需要进一步规范不 动产登记制度。然而, 原有的 “多头登记” 形成的利益 分割格局难打破 [35-37], 不动产的推行过程势必遇到 各种各样的阻力, 不动产统一登记的建立将是一个长期 而艰巨的任务。

随着不动产统一登记推行, 各种各样的推测和争论也 随之而来。有些人认为不动产登记为房地产税铺路, 有利 于反腐, 随着不动产登记条例的出台, 能逼出部分存量的 二手房，而二手房源的增加势必起到抑制房价的作用 [38 - 40]。而有些专家持相反的观点, 认为房价上涨的背 后涉及到的因素复杂, 不动产登记制度很难起到抑制房价 的作用。一方面, 统一登记是一个长期的过程。另一方面, 不动产统一登记仅仅是一项产权制度与信息平台，房屋、 土地或产权登记上的统一，不会对房地产市场产生直接影
响 [41-43]。众学者观点不一, 且目前的研究多基于理论 分析, 缺乏数据支撑。

已有学者的研究在为本文提供借鉴的同时, 也引发如 下关键问题的思考, 既然目前各个部门已经有各自的登记 制度, 是否还有不动产统一登记的必要? 不动产统一登记 的用途究竟是什么? 在推行不动产统一登记的过程中又 会遇到何种阻力? 考虑到房产登记最贴近百姓生活也是 不动产统一登记的最重要部分, 已有的房产登记所折射的 问题，可以由点及面的考察不动产统一登记所反映的问题。 因此本文以已有的房产登记作为研究对象, 在设计调查问 卷并进行结构式访谈的基础上，分析中国已有的房产登记 凭证、登记凭证的重要性、颁证机构、颁证时间、房产登 记的必要性、登记的用途和登记的阻力, 通过数据分析考 察百姓对已推行政策的认可度, 如果多数人支持政策的推 行, 则在政策推行过程中民众所带来的阻力会更小, 因此 考察受访者对政策的认知是研究的重要方面, 最后根据受 访者对调研问题的认知分析不动产统一登记是否有必要, 有何种用途，会遇到何种阻力。

\section{2. 数据来源}

\section{1. 研究地区的基本情况}

本研究选择东、中、西部经济发展情况不同的三个省 进行对比。研究区域包括广东省深圳市、广州市、湖北省 武汉市、陕西省榆林市神木县、绥德县。数据来源于 2014 年的实地调研，共回收有效问卷 170 份，问卷回收有效率 $90.2 \%$ 。所选的三个省区不论经济状况、楼市概况、产权 状况等房地产情况均有较大的不同, 选点具有一定的可比 性和代表性，如表1所示。

表1 研究地区房地产概况。

\begin{tabular}{llll}
\hline 调研地点 & 经济状况 & 房地产概况 & 产权状况 \\
\hline 陕西省绥德县 & 经济不发达地区 & 部分新盘开发 & 房产证和土地证两证分离 \\
陕西省神木县 & 经济萧条 & 大量 “烂尾楼” & 房产证和土地证两证分离 \\
深圳市罗湖区 & 属于深圳中心城区, 经济发达地区 & 部分城中村分布其中, 很少买卖, 较多租赁 & 房产证和土地证合为房地产证, 产权清晰 \\
广州市白云区 & 属于广州老城区, 经济发达地区 & 大量城中村, 很少买卖, 较多租质 & 房产证和土地证合为房地产证 \\
武汉市武昌区 & 武汉核心城区, 经济中等发达地区 & 较多单位福利房, 城中村可见, 但租赁较多 & 房产证和土地证两证分离 \\
\hline
\end{tabular}

表2 受访者基本情况。

\begin{tabular}{|c|c|c|c|c|c|c|c|}
\hline & 类别 & 人数 & 占比 & & 类别 & 人数 & 占比 \\
\hline \multirow{2}{*}{ 性别 } & 男 & 100 & $58.8 \%$ & \multirow{8}{*}{ 最高学历 } & 文盲/半文盲 & 3 & $1.8 \%$ \\
\hline & 女 & 70 & $41.2 \%$ & & 小学 & 7 & 4. $1 \%$ \\
\hline \multirow{4}{*}{ 年龄 } & 20岁及以下 & 1 & $0.6 \%$ & & 初中/中专 & 31 & $18.2 \%$ \\
\hline & 21-40岁 & 79 & $46.5 \%$ & & 高中 & 36 & $21.2 \%$ \\
\hline & 41-60岁 & 51 & $30.0 \%$ & & 大专 & 31 & $18.2 \%$ \\
\hline & 61 岁及以上 & 37 & $21.8 \%$ & & 大学本科 & 39 & $22.9 \%$ \\
\hline \multirow{7}{*}{ 职业 } & 国家机关 & 10 & $5.9 \%$ & & 硕士 & 13 & $7.6 \%$ \\
\hline & 科研、事业单位 & 24 & 14. $1 \%$ & & 博士 & 6 & $3.5 \%$ \\
\hline & 国有企业 & 45 & $26.5 \%$ & \multirow{2}{*}{ 户口 } & 城镇户口 & 131 & 77. $1 \%$ \\
\hline & 三资、私营企业 & 40 & $23.5 \%$ & & 农村户口 & 33 & 19. $4 \%$ \\
\hline & 自由职业者 & 24 & $14.1 \%$ & \multirow{3}{*}{ 户口所在地 } & 本市户口 & 114 & $67.1 \%$ \\
\hline & 农民 & 4 & $2.4 \%$ & & 非本市户口 & 53 & $31.2 \%$ \\
\hline & 无工作 & 21 & $12.4 \%$ & & & & \\
\hline
\end{tabular}




\section{2. 受访者基本情况}

本次调研采用小区内随机抽样, 在充分尊重受访者意 愿的情况下, 客观真诚表达研究的中立性和客观性, 并得 到受访者的理解与支持。在被调查的 170 位受访者中男性 占 $58.8 \%$, 女性占 $41.2 \%$ 。年龄主要集中在 “21-60岁”, 其中 “21-40岁” 占 $46.5 \%, 73.5 \%$ 的受访者具有高中及以 上学历。受访者中城镇户口居多, 占 $77.1 \%$, 本市户口占 $67.1 \%$ 。工作单位分布在国家机关、科研、事业单位、企 业等各类型的服务机构和行业中。总的来说, 样本具有很 好的代表性, 如表2所示。

\section{3. 结果与分析}

\section{1. 研究结果}

\subsection{1. 已有的房产登记}

本文从“有没有房产证”、“房产证是否重要”、“有 没有土地证”、“土地证是否重要” 等角度考察已有的房 产登记凭证和受访者对登记重要性的感知, 具体分析结果 如图1所示。

其中, 由图1-a，1-b可以看出，4个市均是 “有房产 证” 占最大比例, 且不论是 “有房产证” 还是 “没有房产 证” 的受访者, 大部分人均认为 “房产证重要”。只有深 圳市的受访者认为 “房产证不重要” 的人数比 “没有房产
证” 的人数多。对于土地证, 在深圳市和广州市, “没有 土地证” 占最大比例, 而在武汉市和榆林市, “有土地证” 占最大比例。从 “土地证是否重要” 来看, 4 个市均是 “土 地证重要” 占最大比例, 以武汉市为例, 所有受访者均认 为 “土地证重要”。只是在深圳市, 关于 “土地证是否重 要” 的问题较其他省市回答的少。如图1-c, 1-d所示。

总之, 从已有的房产登记可以看出, 武汉市和榆林市 多数人两证俱全, 而深圳市和广州市多数人 “没有土地证”。 从登记凭证的重要性可以看出, 不论是有没有房产证和土 地证, 绝大多数人均认为房产证和土地证 “重要”。

\subsection{2. 受访者了解的颁证机构及颁证时间}

本文从受访者认知的 “房产证颁证单位”、“土地证 颁证单位”、“房产证颁证时间”、“土地证颁证时间” 等问题了解受访者对房地产颁证机构及其颁证时间的认 识, 图2给出了具体统计结果。

其中, 由图2-a可以看出, 在深圳市受访者了解的房 产证颁证机构中, “国土资源局” 占最大比例, 在广州市、 武汉市和榆林市, 房产证的颁证机构 “房管局” 占最大比 例。值得注意的是，房产证的颁证机构包括 “房管局”、 “国土资源局”、“政府”、“城建局”、“开发商”、 “单位” 等诸多单位。图2-b所示的土地证的颁证机关, 均是 “国土资源局” 占最大比例。同样的问题是，土地证 的颁证机关也包括 “国土资源局”、“房管局”、“人民 政府”、“规划局”、“城建局”、“单位”等诸多部门。
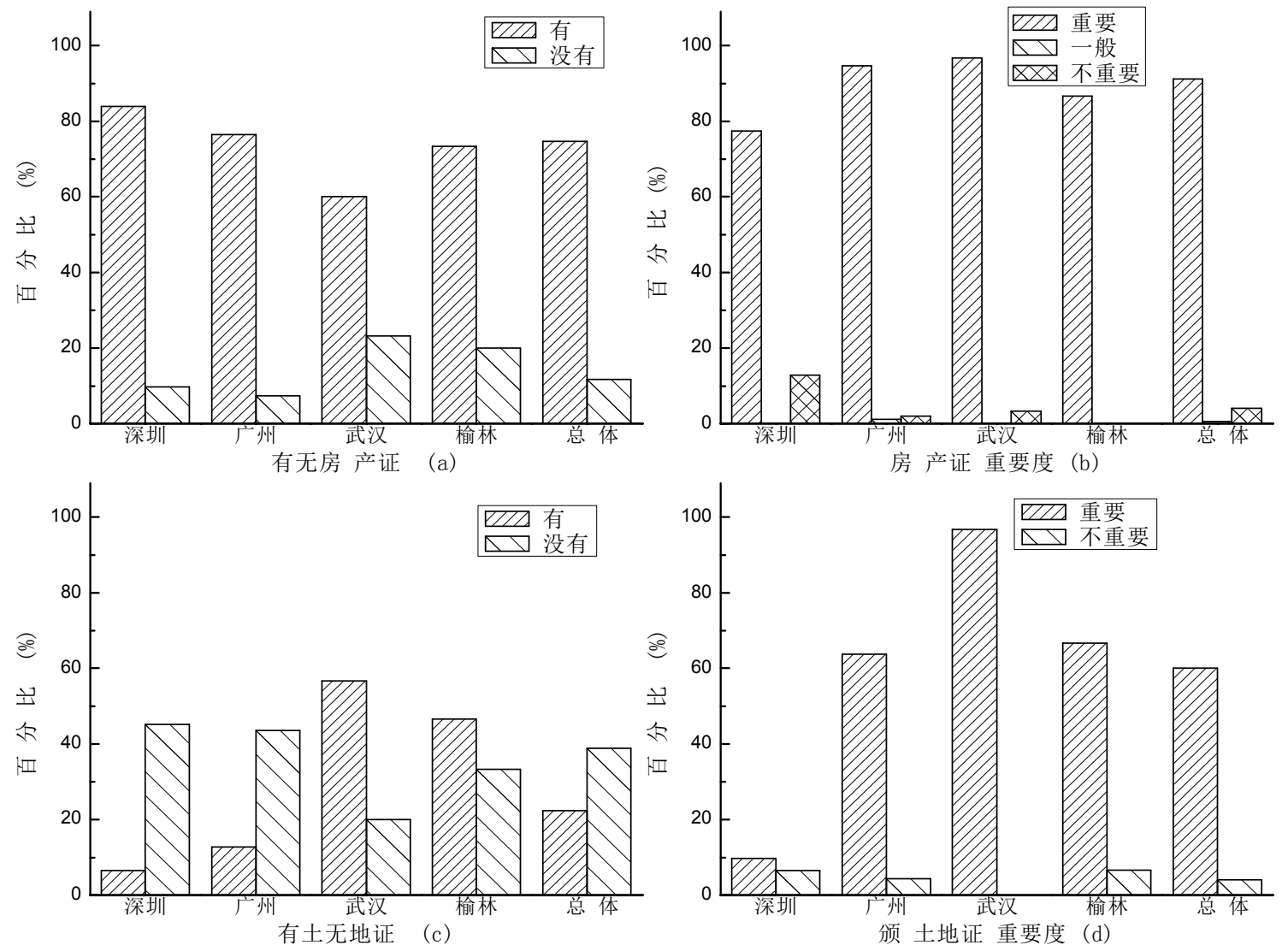

图1 已有的登记凭证。 

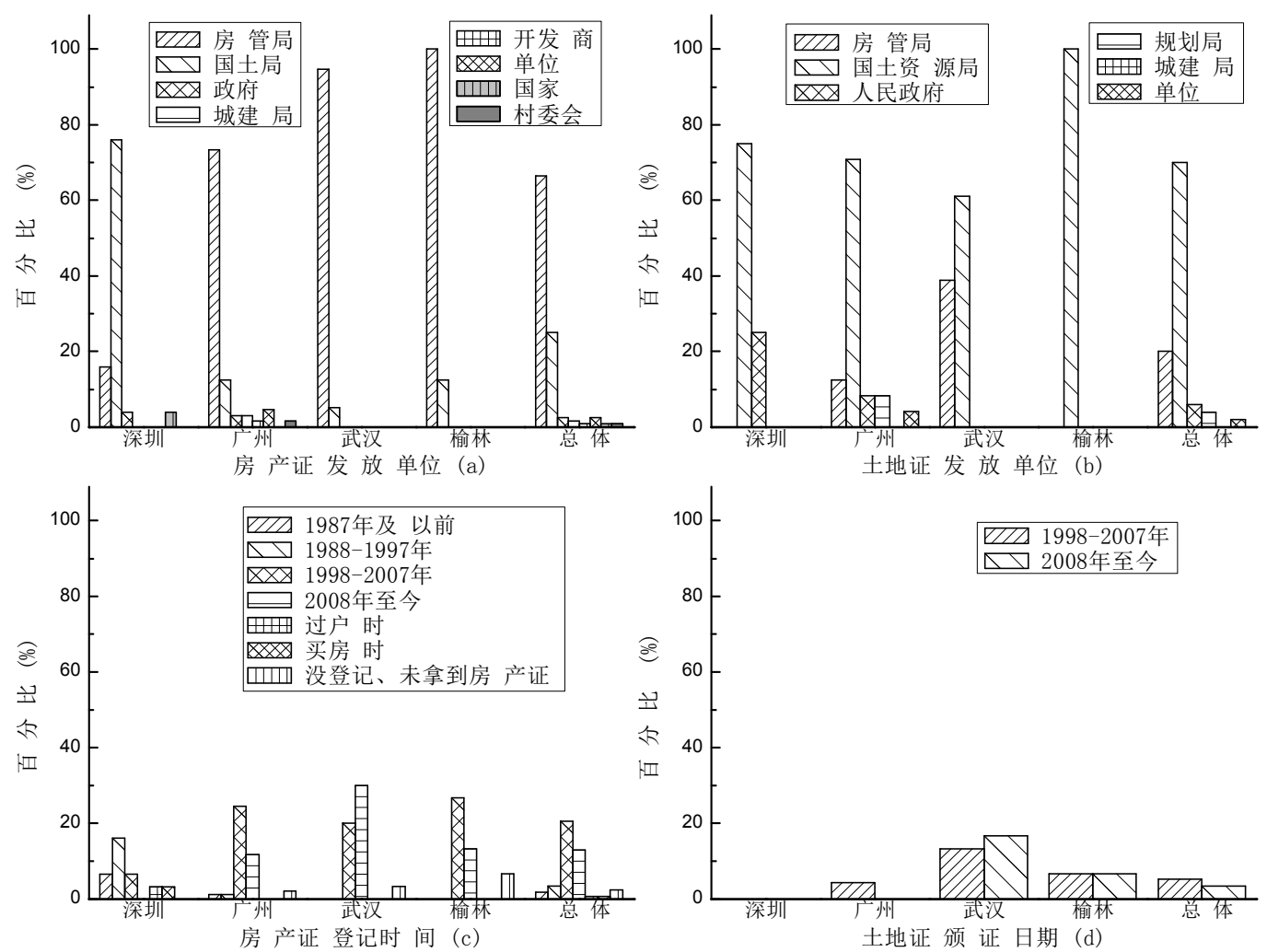

图2 颁证机构和颁证时间。

注: 图1、图2所示问题, 均是受访者的口头表述, 并没有出示相应的产权证件。

从房产证的颁证时间来看, 在深圳市“1988-1997年” 颁证居多，在广州市和榆林市颁证时间大部分在 “1998-2007年”，武汉市多数房产证颁发于 “2008年至 今”。从 4 个市总体来看, 房产证的颁证时间多数在 1998 年以后。对于土地证, 深圳市没有土地证颁证日期, 广州 市土地证颁证日期全部在 “1998-2007年”。对比4个市, 土地证颁证日期全部集中在1998年以后，如图 $2-\mathrm{c}, 2-\mathrm{d}$ 所示。

总之, 从颁证机关可以看出, 在深圳市受访者了解的 房地产证颁证机关主要为 “国土资源局” ，在广州市房地 产证颁证机关主要为 “房管局”，武汉市和榆林市房产证 和土地证两证分离，房产证颁证机关为 “房管局”、土地 证的颁证机关为“国土资源局”。对于房产证的颁证时间， 在深圳市1998年以前颁证占多数, 在广州市、武汉市、榆 林市颁证时间主要集中在1998年以后。对于土地证的颁证 时间，除深圳市外，全部于1998年以后颁证。

\section{1. 3. 房产登记推行的作用}

本文从“是否听过房产登记”、“对房产登记必要性 的看法”、“已有房产登记是否需要规范”、“房产登记 的用途” 等问题，对目前房产登记政策普及性、百姓支持 度及房产登记用途等问题进行分析, 具体分析结果如图3 所示。

从 4 个市来看, 多数受访者听说过房产登记, 并认为 有必要进行房产登记, 只有 $4.1 \%$ 的受访者认为没必要进行 房产登记。在深圳市, 不论是有没有听说过房产登记的受
访者, 所有人均认为有必要进行房产登记, 如图3-a、3-b 所示。对于已有的房产登记, 多数人认为还需要继续规范, 只有 $5.9 \%$ 的受访者认为不需要继续规范房产登记。从武汉 市来看, 全部受访者均认为需要继续规范房产登记, 如图 3-c所示。由图3-d可以看出, 从4个市的总体来看, 房产 登记的主要用途为 “反腐”、“国家信息掌控”、“房地 产市场规范化”。其中，在深圳市 “国家信息掌控” 占最 大比例, 广州市 “房地产市场规范化” 占最大比例, 武汉 市和榆林市 “反腐” 占最大比例。

总之, 从 “是否听过房产登记” 和 “房产登记的必要 性” 可以看出, 多数人听过房产登记, 且认为有必要进行 房产登记。从 “是否需要规范房产登记” 和 “房产登记的 用途” 可以看出多数人认为需要规范房产登记, 而登记的 用途主要是 “反腐”、“国家信息掌控”、“房地产市场 规范化” 等。

\section{1. 4. 房产登记的阻力}

图4给出房产登记阻力的统计结果。图4-a所示为不考 虑 “不知道” 房产登记和对房产登记持 “无所谓” 态度人 群后的统计结果。图中可以清楚看出, 在所有回答房产登 记有无阻力的人群中, 大部分受访者认为房产登记会遇到 阻力。各市房产登记的主要阻力均来源于特定人群 (如官 员、富人、思想保守人等），图中称 “人群阻力” , 支持 “人群阻力” 观点的人数占总人数的 $73.3 \%$ 。除 “人群阻 力” 外, 深圳市、广州市和榆林市 “税收、限购等国家政 策的推行”也是房产统一登记的重要阻力, 如图4-b所示。 

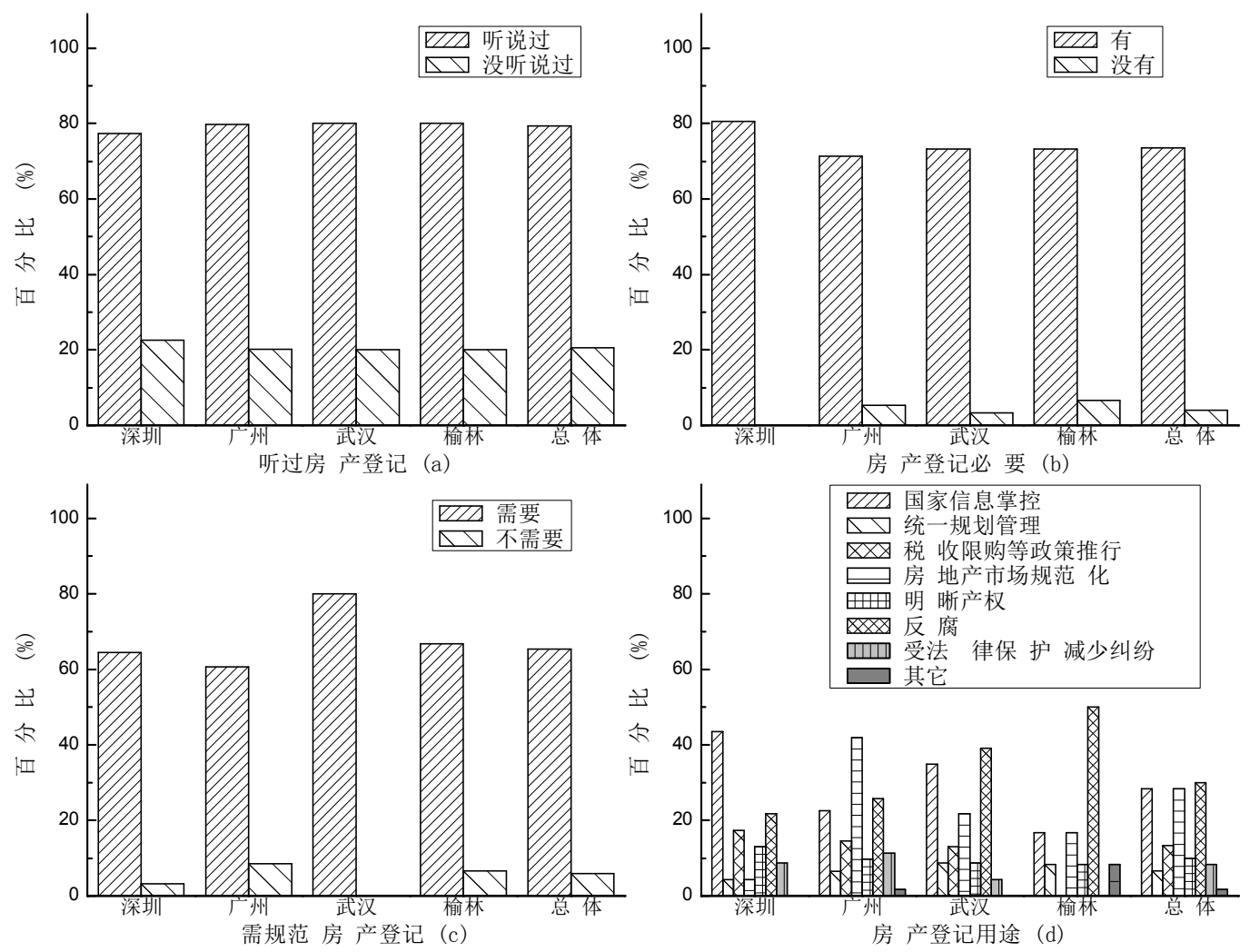

图3 房产登记推行的作用。
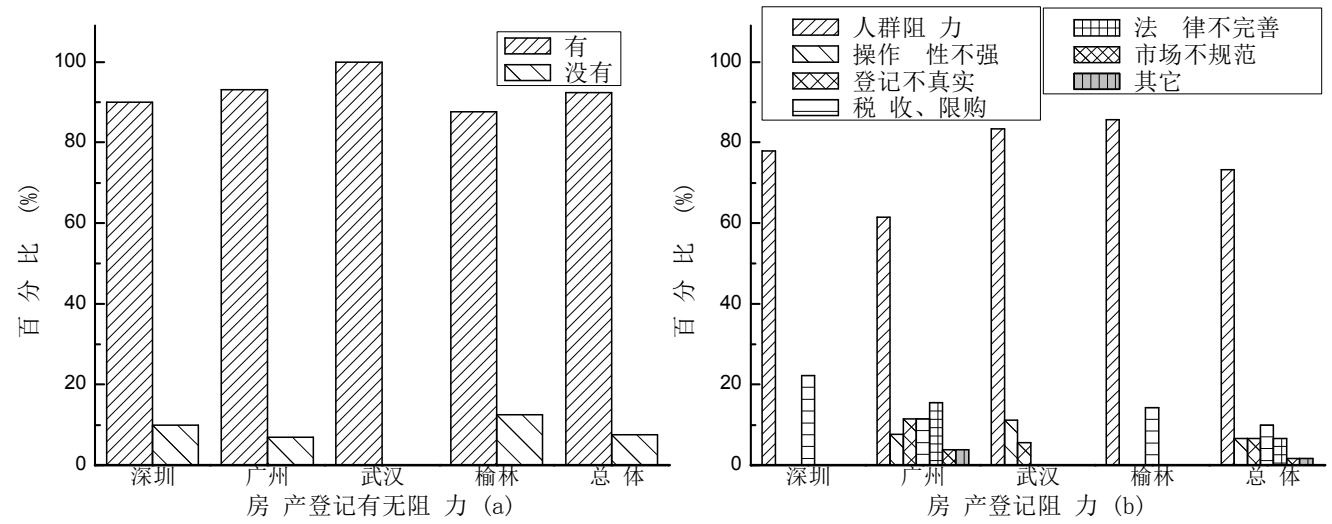

图4 房产登记的阻力。

\section{2. 结果分析}

（1）通过受访者对 “有没有房产证”、“房产证是 否重要”、“有没有土地证”、“土地证是否重要”等问 题的回答分析受访者对中国目前已有的登记凭证的认识。 对于有没有房产证问题，4个市均是 “有房产证” 占最大 比例, 可以表明目前各地具有一定的房产登记。值得注意 的是，在武汉市和榆林市 “没有房产证” 的比例均大于 $20.0 \%$, 而深圳市和广州市均小于 $10.0 \%$ 。这说明在深圳市 和广州市等发达地区的房产证普及率更高。对于 “没有房 产证” 的住户考虑有如下原因: 一、该地区房地产市场混 乱, 五证不全的开发商在没有资质的情况下, 擅自预售, 导致楼房交工后相关的产权证件办不下来; 二、购房者产
权意识不清, 未通过正规渠道购房导致的没有相关购房凭 证; 三、购房者因为不愿意交高额的税费, 所以在不影响 居住的情况下不愿意去办理相关的产权证件。从 “有没有 土地证” 可以看出, 深圳市和广州市 “没有土地证” 占最 大比例, 考虑其原因是因为深圳市和广州市目前实行房地 合一的产权制度, 将房产证和土地证统一为房地产证, 没 有独立的土地证, 另外受访者对于已有的产权证件了解不 清。而对于武汉市和榆林市 “有土地证” 占最大比例, 考 虑到武汉市和榆林市目前实行的是房地分离的产权制度。 此外，对于 “房产证是否重要” 问题，不论是有没有房产 证, 受访者都认为颁发 “房产证重要”。对于 “土地证是 否重要” 的问题, 无论受访者有没有土地证, 都认为颁发 
“土地证重要”。这说明受访者认识到产权登记证件的重 要性, 有利于产权登记政策的推行。

(2) 通过 “房产证颁证单位”、“土地证颁证单位”、 “房产证颁证时间”、“土地证颁证时间” 等问题分析受 访者对目前的颁证机构和颁证时间的认识。从 “房产证颁 证单位” 可以看出, 深圳市的多数受访者认为 “国土局” 是房产证的主要发证单位, 而广州市的多数受访者认为 “房管局” 是主要发证单位。从官方的颁证机构来看, 深 圳市和广州市的颁证单位都是国土资源和房产管理局。因 此很多受访者对产权证件的颁证单位并不是特别清楚, 有 受访者表示只知道有一个证, 具体没仔细看过。而在武汉 市和榆林市的受访者多数认为房产证的发放单位是 “房管 局”，也有少部分受访者认为是 “国土局”。从房产证的 官方颁证机构来看, 武汉市是住房保障和房屋管理局, 榆 林市是住房和城乡建设局, 因此多数的受访者认识到房产 证的颁证单位, 但只知道颁证机构的简称, 小部分受访者 认识不清。从土地证发放单位可以看出, 各地的受访者认 识到的土地证颁证单位基本上都是 “国土资源局” 。从土 地证的官方颁证机构来看, 武汉市是国土资源和规划局, 榆林市是国土资源局。另外, 值得注意的是, 在深圳市和 广州市存在多种形式的房产证颁证单位。对于这种情况考 虑有如下原因: 一、受访者对颁证机构的认识不清; 二、 深圳市和广州市地处经济发达地区, 高昂的商品房房价导 致买不起房的群体庞大, 部分人通过购买小产权房等不正 规房产类型解决住房问题, 不正规的房产类型具有很大的 销售空间, 需求的增加促进了供给的多样, 并衍生出多样 的颁证单位。同样的问题是, 除了榆林市外, 深圳市、广 州市、武汉市均存在多种形式的土地证发证单位, 以广州 市最为严重。从房产证颁证日期可以看出，除深圳市 1998 年以前颁证占大部分比例外, 其他 3 个市均是 1998 年以后 占绝大部分比例, 值得注意的是武汉市和榆林市全部都是 1998年以后颁证。从上述分析可以看出, 深圳市颁发房产 证较早, 考虑到经济特区, 房产登记推行较早, 与实际相 符。从土地证颁证日期可以看出，所有持有土地证的购房 者均是1998年以后颁证。深圳市没有颁发土地证的日期, 考虑到深圳市房地合一的产权制度，并没有单独的土地证。 从上述分析可以看出, 中国的房地产证颁证制度主要是从 1998年住房改革开始, 1998年以后房地产发证制度逐渐正 规。但是目前多元的登记机构依然存在, 进一步证明了目 前的房地产登记虽有一定的工作基础，但是并不完善。

(3) 通过 “是否听过房产登记”、“房产登记的必 要性”、“是否需要规范房产登记”、“房产登记的用途” 等问题分析目前房产登记的政策普及性、百姓支持度及房 产登记的用途等问题。从“是否听过房产登记”可以看出, 约有 $1 / 5$ 的受访者 “没听过房产登记”，考虑到有两方面 原因: 一、房产登记制度的普及性有限, 二、部分受访者 受到自身教育背景和职业的限制, 比如受教育程度较低或 没接受过正规教育、长期居家脱离社会等。另外, 根据地 区之间的差异性分析表明，“听说过房产登记” 的地区间 标准差为 $1.1 \%$, 差异较小。从 “房产登记必要性” 可以看 出, 绝大部分受访者认为 “有必要进行房产登记”, 这些 受访者中有部分人认为官员有必要、老百姓没必要。这说
明房产登记制度受到百姓支持的一部分原因是有些人认 为房产登记制度能起到反腐的效果。同时 “有必要进行房 产登记” 的地区间标准差为 $3.8 \%$, 说明地区间差异较小。 总体来看具有高的百姓支持率。从 “是否需要规范房产登 记”的问题中, 绝大部分受访者认为 “需要规范房产登记”, 考虑原因是目前多元的登记机构, 房地产登记要跑几个部 门, 登记制度长期不规范等问题。“需要继续规范房产登 记” 的地区间标准差为 $7.3 \%$, 说明对于此问题的观点具有 一定的地区差异性。从 “房产登记的用途” 可以看出受访 者理解的房产登记的用途主要包括: “反腐”工作的推行; 干部摸底、审查备案等国家信息的宏观掌控; 平抑房价、 买卖公平、限制炒房、抑制空置率等房地产市场规范化; 税收、限购等国家相关政策的推行; 产权的明晰; 权利人 受法律保护以减少纠纷; 调整供需、宏观调控等统一规划 管理。对于房产登记的用途, 其中不动产登记能 “规范房 地产市场”、起到 “反腐” 效果和利于 “国家信息掌控” 几个用途的地区间标准差分别为 $13.6 \% 、 11.2 \%$ 和 $10.4 \%$, 其他用途的地区间标准差均小于 $7.0 \%$, 说明不动产登记是 否能够 “规范房地产市场”、起到 “反腐” 效果和利于 “国 家信息掌控” 与其他用途相比在地区间差异更大。上述分 析可以看出不论是百姓的高支持率还是房产登记的诸多 用途都说明房产登记是利国利民的好政策, 有利于不动产 统一登记的推行。

（4）房产登记的阻力分析包括以下三方面: 第一、 是否听过房产登记? 第二、不动产登记有无阻力? 第三、 房产登记的阻力包括什么方面? 数据分析过程中不考虑 “不知道” 房产登记, 或对房产登记 “无所谓” 等态度的 人群, 仅针对房产登记有无阻力分析可以看出, 多数受访 者认为房产登记推行过程中会遇到阻力, 并且房产登记阻 力的地区间标准差为 $4.7 \%$, 差异不大。阻力可以归纳为如 下几个方面: 官员、富人、思想保守人等人群的阻力; 税 收限购等国家政策的推行; 工作量大、程序麻烦、收效小 等具体操作层面的阻力; 登记假信息、隐瞒不报、房产分 散、流动资金查不到等登记真实性难保证的问题; 制度漏 洞、法律不完善、国家政策难落实的困难; 已有炒房、乱 买乱卖等房产市场不规范等阻力。其中 “官员、富人、思 想保守的人等人群” 是房产登记的主要阻力, $73.3 \%$ 的受 访者支持这一观点。另外, 在进行官方访谈的过程中, 部 分受访者认为如果国家想推行不动产统一登记, 制度推行 没有问题, 但困难依然存在。比如机构体制问题; 自负盈 亏登记机构人员的编制解决问题; 不同时间登记内容的衔 接问题; 现有登记体制是 “属地登记”，原有的利益格局 打破, 登记工作动力不足等问题。

\section{4. 结论}

本文以现有的房产登记作为研究对象，在设计调查问 卷并进行结构式访谈的基础上, 分析中国房产登记凭证及 其重要性、颁证机构及其颁证时间、房产登记的必要性以 及登记用途和阻力, 考察已有房产登记体制的不足, 并结 合不动产统一登记、不动产登记、房产登记等的已有研究 
成果对不动产统一登记的用途和阻力进行统计分析, 分析 结果如下:

(1) 不动产统一登记的必要性

数据表明, 只有 $4.1 \%$ 的受访者认为 “没必要进行房产 登记” , 绝大多数受访者认为 “有必要进行房产登记”, 这些受访者中有部分人认为官员有必要、老百姓没必要。 同时 “有必要进行房产登记” 的地区间标准差为 $3.8 \%$, 说 明地区间差异较小。另外，只有 $5.9 \%$ 的受访者认为 “不需 要规范房产登记”, 绝大部分受访者认为 “需要规范房产 登记”, “需要继续规范房产登记” 的地区间标准差为 $7.3 \%$, 具有一定的地区差异性。综上所述不动产统一登记具有高 的百姓支持率, 有必要进行不动产统一登记。

(2) 不动产登记的用途

数据分析结果表明房产登记的用途主要包括: 反腐; 国家信息掌控; 房地产市场规范化; 税收限购等政策进一 步推行; 明晰产权; 受法律保护, 减少纠纷; 统一规划管 理等。另外, 不动产登记是否能够 “规范房地产市场” 、 起到 “反腐” 效果和利于 “国家信息掌控” 几个用途的地 区间标准差分别为 $13.6 \% 、 11.2 \%$ 和 $10.4 \%$, 其他用途的地 区间标准差均小于 $7.0 \%$, “规范房地产市场”、起到 “反 腐” 效果和利于 “国家信息掌控” 与其他用途相比在地区 间差异更大。

(3) 不动产登记的阻力

数据分析表明在不考虑 “不知道” 房产登记和对房产 登记持 “无所谓” 态度的受访者的情况下, 仅针对房产登 记有无阻力可以看出, 多数受访者认为房产登记推行过程 中会遇到阻力, 并且房产登记有无阻力的地区间标准差为 4. 7\%, 差异不大。房产登记阻力主要包括: 人群阻力; 税 收限购等国家政策; 具体操作性不强; 登记真实性难保证, 调查不清; 制度漏洞、法律不完善、国家政策难落实; 已 有房产市场不规范等阻力。

总之, 中国有必要进行不动产统一登记, 不动产统一 登记具有诸多用途, 但是在不动产统一登记的推行过程中 会遇到各种各样的阻力。因此, 在不动产统一登记的推行 过程中, 需要做大量的基础工作, 如理顺现有的机构体制、 解决登记人员的安置、构建统一的不动产登记电子平台、 建立不动产统一登记的监督问责机制等, 不动产统一登记 将是一个长期的过程, 切勿急功近利。

\section{致谢}

本文为国家自然科学基金面上项目《基于土地制度变 迁视角的中小城镇发展模式研究》（No. 71473286）的阶 段性成果之一。

\section{参考文献}

[1] 黄亮. 划拨土地使用权抵押立法矛盾之探析 $[J]$. 中国土地 科学, 2007, 21 (3):64-68。

[2] 施正文. 《物权法》实施与开征物业税 $[J]$. 税法理论与实 务, 2008(9):53-56。
[3] 周珺. 从两个 “办法” 看不动产统一登记制度的前景 $[\mathrm{J}]$. 暨南学报 (哲学社会科学版), 2009, 31 (1): 14-16。

[4] 施昱年, 蔡宗翰, 陈丽, 林增杰. 基于AHP构建中国不动产 登记制度的分析 [J]. 中国土地科学, 2009, 23(6):5155,60 。

[5] 石晓莉. 进一步完善不动产登记制度 $[\mathrm{J}]$. 四川师范大学学 报（社会科学版）, 2009, 36(5):53-58。

[6]向明. 论中国不动产登记机关的合理选择 [J]. 甘肃社会科 学, $2010(4): 48-51$ 。

[7] 陈龙江. 中国《物权法》不动产登记效力之评析 $[\mathrm{J}]$. 海南大 学学报人文社会科学版, 2010, 28(3):55-61。

［8］朱晓吉. 房、地分离抵押的法律效果《物权法》第182条的 法律教义学分析 $[J]$. 华东政法大学学报, 2010 (1) : 15 - 31。

［9］刘璐. 统一不动产登记制之下的土地登记规则一一以《土地 管理法修订案送审稿》第三章为分析对象 $[\mathrm{J}]$. 政治与法 律, 2012(5): $14-21$ 。

[10] 何欢乐, 姜栋, 张鹏. 切实推进中国不动产统一登记的新思 路——解决分散登记问题的过渡期方案 [J]. 中国土地科 学, 2013, 27 (7): 10 - 14。

[11] 黄志凌, 姜栋, 严金明. 瑞典不动产登记法律制度研究与借 鉴 $[J]$. 中国土地科学, 2013, 27 (2):73-79。

[12］于海涌. 论实质审查与登记机关谨慎义务的边界一一以房 屋登记办法》为中心 $[\mathrm{J}]$. 暨南学报 (哲学社会科学 版), 2009, 31 (1):8-11。

[13] 高圣平. 《物权法》视野下的《土地管理法》修改 [J]. 中国 土地科学, 2008, 22(7):3-10。

[14] 高圣平.《物权法》背景下的《城市房地产管理法》修改一一 兼及部门法的立法技术 $[\mathrm{J}]$. 中国人民大学学 报, 2008(2): 122-129。

[15] 黄健雄. 试论中国房地产登记法律制度的完善 [J]. 厦门大 学学报（哲社版）, 1997(1):48-53。

[16] 张曼莉. 不动产预告登记制度研究 [J]. 社会科学辑 刊, 2009 (1):63-65。

[17] 彭建新. “双方申请原则”之下的不动产登记制度构建 一一债权形式主义下的履行抗辩与利益平衡为中心 $[\mathrm{J}]$. 政 治与法律, 2013(4) : 77 - 84。

[18］范利平，孙东海. 中国香港房地产登记制度的经验及借鉴 $[J]$. 法学杂志, 2011 (12) :86 - 89。

[19] 孙静. 德国的土地登记簿制度及对我们的启示 [J]. 中国房 地产, 1997 (10): 73 - 75。

[20] 向明. 不动产登记程序研究 $[J]$. 宁夏社会科 学, 2011(4): 16 - 22。

[21] 向明. 中国不动产登记簿制度研究 [J]. 政治与法 律, 2011(2): 152 - 160。

[22] 屈茂辉. 不动产登记申请的法理与规则 $[J]$. 法学研 究, 2007 (2) : 89-98。 
[23] 邵亚萍. 行政法视野下的不动产登记审查标准一一以房产 登记为例 $[J]$. 浙江学刊, 2009 (4) : 155-159。

[24] 黄莹, 吴鹏. 论不动产登记的查询主体 [J]. 法学评 论, 2009 (3) : 130 - 134。

[25] 常鹏朝. 不动产登记簿的制度建构 [J]. 法律科学 (西北政法 大学学报), 2009 (5) : 128-135。

[26] 程啸. 不动产登记簿错误之类型与更正登记 [J]. 法律科学 (西北政法大学学报), 2011(4): 164-174。

[27] 程啸. 不动产登记簿之推定力 $[\mathrm{J}]$. 法学研 究, 2010(3) : 106 - 119。

[28] 侯水平, 周中举. 2007 不动产登记中真实权利人保护研究 [J]. 社会科学研究, 2007 (1) : 93 - 98。

[29] 熊玉 梅. 论不动产物权登记之效力 $[\mathrm{J}]$. 求 索, 2008(12): 148 - 150。

[30] 陈坚. 中国物权登记行为的性质与法律效力辨析 $[\mathrm{J}]$. 求 索, 2012 (5) : 243-245。

[31] 杨利民. 不动产统一登记：如何 “破阻前行” [J]. 中国土 地, 2014(5):20-22。

[32] 江玉桥, 践浩飞. “统一”之路立法为先一对不动产统一登 记立法工作的完善意见 [J]. 中国土地, 2014(5) :25-26。

[33] 朱珍华. 不动产统一登记制度建构新探 $[\mathrm{J}]$. 广西民族大学 学报（哲学社会科学版）, 2014, 36(5) : 160-164。
[34] 杨宏云. 房屋登记的效力及其制度完善 [J]. 青海社会科 学, 2010(1):171 - 174。

[35] 赵剑桥, 司静波, 韩立伟, 张忆. 农村不动产统一登记制度 实施的必要性和阻力分析 $[\mathrm{J}]$. 安徽农业科 学, 2014, 42 (19):6438, 6440。

[36] 赵永慧, 贾广葆. 不动产统一登记的难点及实施路径 $[J]$. 城乡建设, 2014(3):80-82。

[37] 马安胜, 姚华军, 袁国华. 不动产统一登记的难点与政策建 议 [J]. 国土资源科技管理, 2015, 32(1):64-68。

[38] 间飞. 浅谈不动产统一登记制度的阻力与潜在影响 [J]. 法 制与社会, 2014(7):91-92。

[39] 马建宇, 耿明斋, 曹青. 对不动产登记及征税的思考和建议 [J]. 宏观经济管理, 2014(11):68-69。

[40] 安体富, 葛静. 关于房地产税立法的几个相关问题研究 [J]. 财贸经济, 2014(8): 5 - 12, 48。

[41] 孙军. 房产登记档案查询制度在法治社会中的承载一从 “房妹”、“房叔”、“房姐” 到 “限制以人查房” 的思 考 $[J]$. 档案学通讯, 2013(3):61 - 64。

[42] 孙宪忠. 不动产登记基本范畴解析 [J]. 法学 家, 2014 (6) : 12 - 25。

[43] 周江. 不动产统一登记的意义 [J]. 中国金融, 2015 (6) :8687 。 